\title{
Beet curly top virus Strains Associated with Sugar Beet in Idaho, Oregon, and a Western U.S. Collection
}

Carl A. Strausbaugh and Imad A. Eujayl, United States Department of Agriculture-Agricultural Research Service (USDA-ARS) Northwest Irrigation and Soils Research Laboratory, Kimberly, ID 83341; and William M. Wintermantel, USDA-ARS, Salinas, CA 93905

\begin{abstract}
Curly top of sugar beet is a serious, yield-limiting disease in semiarid production areas caused by Beet curly top virus (BCTV) and transmitted by the beet leafhopper. One of the primary means of control for BCTV in sugar beet is host resistance but effectiveness of resistance can vary among BCTV strains. Strain prevalence among BCTV populations was last investigated in Idaho and Oregon during a 2006-to-2007 collection but changes in disease severity suggested a need for reevaluation. Therefore, 406 leaf samples symptomatic for curly top were collected from sugar beet plants in commercial sugar beet fields in Idaho and Oregon from 2012 to 2015. DNA was isolated and BCTV strain composition was investigated based on polymerase chain reaction assays with strain-specific primers for the Severe (Svr) and California/Logan (CA/

Logan) strains and primers that amplified a group of Worland (Wor)like strains. The BCTV strain distribution averaged $2 \%$ Svr, 30\% CA/ Logan, and $87 \%$ Wor-like (16\% had mixed infections), which differed from the previously published 2006-to-2007 collection (87\% Svr, 7\% CA/Logan, and $60 \%$ Wor-like; $59 \%$ mixed infections) based on a contingency test $(P<0.0001)$. Whole-genome sequencing (GenBank accessions KT276895 to KT276920 and KX867015 to KX867057) with overlapping primers found that the Wor-like strains included Wor, Colorado and a previously undescribed strain designated Kimberly 1 . Results confirm a shift from Svr being one of the dominant BCTV strains in commercial sugar beet fields in 2006 to 2007 to becoming undetectable at times during recent years.
\end{abstract}

Beet curly top virus (BCTV) in sugar beet (Beta vulgaris L.) is an important yield-limiting disease problem in semiarid production areas of the western United States and in Middle Eastern countries (Bennett 1971; Gharouni Kardani et al. 2013; Harveson 2015; Stenger and McMahon 1997; Strausbaugh et al. 2008; Yazdi et al. 2008). BCTV is transmitted in a persistent circulative manner by the beet leafhopper, Circulifer tenellus Baker (Hemiptera: Cicadellidae), and can infect over 300 dicotyledonous plant species (Bennett 1971). Yield may be affected in important crops such as common bean, pepper, spinach, sugar beet, and tomato (Blickenstaff and Traveller 1979; Chen and Gilbertson 2009; Creamer et al. 1996; Soto and Gilbertson 2003; Soto et al. 2005). Several distinct, genetically characterized members of the genus Curtovirus have been confirmed as causative agents of curly top in sugar beet (Briddon et al. 1998; Gharouni Kardani et al. 2013; Heydarnejad et al. 2007, 2013; Soleimani et al. 2013; Stenger 1998; Strausbaugh et al. 2008; Yazdi et al. 2008). However, reevaluation of the genus Curtovirus assigned most of these viruses formerly recognized as distinct Curtovirus spp. as strains of BCTV (Varsani et al. 2014a).

Curtovirus isolates and strains with greater than $94 \%$ sequence identity are now considered variants of the same strain and those with $77 \%$ or less sequence identity are considered different species (Varsani et al. 2014a). Therefore, several widely recognized Curtovirus spp. affecting sugar beet and vegetable agriculture in the western United States that were previously considered separate species are now recognized as strains of BCTV. These include California/

Corresponding author: C. A. Strausbaugh;

E-mail: carl.strausbaugh@ars.usda.gov

Mention of trade names or commercial products in this article is solely for the purpose of providing scientific information and does not imply recommendation or endorsement by the U.S. Department of Agriculture.

*The $\boldsymbol{e}$-Xtra logo stands for "electronic extra" and indicates that two supplementary tables are published online.

Accepted for publication 18 April 2017

This article is in the public domain and not copyrightable. It may be freely reprinted with customary crediting of the source. The American Phytopathological Society, 2017.
Logan (CA/Logan; also previously referred to as Beet curly top virus, California and Logan); Colorado (CO; also previously referred to as Beet curly top virus and pCO-95-6-31); Mild (Mld; also previously referred to as Beet mild curly top virus, 8-10, SLP1, BMCTVMexico, and MX-P24); Pepper curly top (PeCT; also previously known as Pepper curly top virus, BV3, and NM); Pepper yellow dwarf (PeYD; also previously known as Pepper yellow dwarf virus); Severe (Svr; also previously referred to as Beet severe curly top virus, $\mathrm{CFH}$, and BCTV-I); Spinach curly top (SpCT; also previously known as Spinach curly top virus and $\mathrm{Sp} 3$ ); and Worland (Wor; also previously referred to as Beet mild curly top virus and Worland4) (Baliji et al. 2004; Briddon et al. 1998; Chen et al. 2011; Hernandez and Brown 2010; Lam et al. 2009; Stenger 1994; Varsani et al. 2014a; Velásquez-Valle et al. 2008; Velasquez-Valle et al. 2012). In addition to BCTV, there are two additional Curtovirus spp.: Spinach severe curly top virus (SpSCTV) and Horseradish curly top virus (HCTV) (Hernandez and Brown 2010; Klute et al. 1996; Varsani et al. 2014a). Viruses in the genus Becurtovirus also infect sugar beet and cause curly top symptoms. These viruses include both Beet curly top Iran virus and Spinach curly top Arizona virus (Gharouni Kardani et al. 2013; Hernández-Zepeda et al. 2013; Heydarnejad et al. 2007, 2013; Soleimani et al. 2013, Varsani et al. 2014b, Yazdi et al. 2008).

BCTV almost eliminated sugar beet production in the western United States in the 1920s and early 1930s until resistant cultivars were developed (Bennett 1971; Panella et al. 2014). Resistant cultivars remain an important control measure; however, most commercial cultivars only contain low to moderate levels of resistance, because the resistance is thought to be quantitatively inherited and is difficult to maintain in parental lines used to create commercial hybrids (Gillen et al. 2008; Kaffka et al. 2002; Panella et al. 2014; Strausbaugh et al. 2007). Alternative control measures to supplement host resistance have been investigated and the most effective has been the use of neonicotinoid seed treatments based on the active ingredients clothianidin and thiamethoxam (Strausbaugh et al. 2006, 2010, 2012, 2014). Clothianidin (sold as Poncho and NipsIt) has been shown to increase sugar beet yields by $17 \%$ or more in heavily infested commercial fields (Strausbaugh et al. 2006, 2010, 2012, 2014). As a result, some sugar beet production areas now require the use of the neonicotinoid seed treatments (Strausbaugh et al. 2012, 2014). Genetic engineering may offer opportunities for controlling curly top in sugar beet but, to date, disease-resistant transgenic 
sugar beet cultivars have not been deployed (Ali et al. 2015; Aregger et al. 2012; Golenberg et al. 2009; Hohn and Vazquez 2011; Horn et al. 2011; Ji et al. 2015; Lee et al. 2013; Sahu and Prasad 2015; Sharma et al. 2012; Wang et al. 2012; Zaidi et al. 2016).

Host resistance remains important to sugar beet producers (Strausbaugh et al. 2016). However, some BCTV strains can be more severe than others on sugar beet and resistance can be both general and strain specific, depending on the source of resistance (Montazeri et al. 2016). Therefore, composition and prevalence of strains and variants should be monitored in sugar beet production areas in order to address changes that may influence the performance of commercial cultivars which only contain low to moderate resistance. Several new species or strains associated with curly top have been identified in various agricultural crops. These are likely the result of recombination among strains and variants during mixed infections, and emerge as significant proportions of the virus population due to selection pressures (Bach and Jeske 2014; Briddon et al. 2010; Chen et al. 2010, 2014; Creamer et al. 2005; Hernandez and Brown 2010; Hernández-Zepeda et al. 2013; Lefeuvre and Moriones 2015; Padidam et al. 1999; Razavinejad et al. 2013; Stenger 1998; Stenger and McMahon 1997, Stenger and Ostrow 1996, Stenger et al. 1990, 1994; Strausbaugh et al. 2008). In an effort to increase our knowledge of the species and strains currently associated with curly top in sugar beet production in Oregon and Idaho, commercial fields were sampled from 2012 to 2015 . To support the primer-based identification, whole-genome sequencing for the BCTV isolates was used to evaluate and validate performance of strain-specific detection methods, and to determine whether the predominant BCTV variants or strains have changed since the 2006-to-2007 collection (Strausbaugh et al. 2008). Results demonstrated a distinct shift in the presence and prevalence of BCTV strains, including the emergence of new variants that justify increased monitoring.

\section{Materials and Methods}

Collection. Curly top symptomatic samples from individual sugar beet plants were randomly collected from commercial fields in southern Idaho and southeastern Oregon from 2012 to 2015, and compared with those collected previously in 2006 and 2007 (Strausbaugh et al. 2008). Samples of new (still expanding) leaves were identified by the presence of typical curly top disease symptoms, including upward and inward rolling of leaves, enations, roughness and thickening of veins, and leaf dwarfing (Wintermantel 2009). In total, 406 plant samples were collected during 2012 (50 plants), 2013 (72 plants), 2014 (131 plants), and 2015 (153 plants) (Supplementary Table S1). These samples were compared with the 266 samples collected in 2006 (119 plants) and 2007 (147 plants). Cultivar names were not tracked during the collections, because the compliment of resistance genes they contain is unknown or not public knowledge and the cultivars available change regularly. Of the 26 cultivars available for the Idaho-Oregon production area in 2012, only 9 were still available to growers in 2015. None of the cultivars in production during the 2006-to-2007 collection were still in production after 2008, because the industry switched to glyphosate-resistant cultivars (Panella et al. 2014).

Strain distribution. Leaf tissue was sampled by taking leaf punches with the cap of a sterile 2-ml microcentrifuge tube from each of three leaves per plant ( $=$ one sample) and stored at $-80^{\circ} \mathrm{C}$ in the microcentrifuge tube. The frozen leaf samples were lyophilized, then pulverized using a Retch MM301 mixer mill (Retch Inc., Newton, PA) with 5-mm-diameter stainless steel beads. DNA was extracted using the DNeasy Plant Mini Isolation Kit (Qiagen Inc., Valencia, CA), assessed via gel electrophoresis, quantified using a BioPhotometer (Eppendorf AG, Hamburg, Germany), and stored at $-20^{\circ} \mathrm{C}$. Polymerase chain reaction (PCR) assays for detection of BCTV were performed in 20- $\mu \mathrm{l}$ volumes: $8.8 \mu \mathrm{l}$ of molecular-grade water (5 Prime Inc., Gaithersburg, MD), $4 \mu \mathrm{l}$ of $5 \times$ Green GoTaq buffer (pH 8.5, with $7.5 \mathrm{mM} \mathrm{MgCl}$; Promega Corp., Madison, WI), $0.6 \mu \mathrm{l}$ of $25 \mathrm{mM} \mathrm{MgCl}$ (Applied Biosystems, Foster City, CA), $0.4 \mu \mathrm{l}$ of $10 \mathrm{mM}$ dNTP (Promega Corp.), $2 \mu \mathrm{l}$ of $3 \mathrm{mM}$ each primer
(Integrated DNA Technologies, Coralville, IA), $0.2 \mu \mathrm{l}$ of GoTaq DNA polymerase (Promega Corp.), and $2 \mu \mathrm{l}$ (approximately $20 \mathrm{ng}$ DNA) of target DNA. The amplification cycle consisted of 3 min at $95^{\circ} \mathrm{C}$ followed by 35 cycles of $95^{\circ} \mathrm{C}$ for $30 \mathrm{~s}, 55$ to $57^{\circ} \mathrm{C}$ (depending on primer pair, as indicated in Supplementary Table S2) for $30 \mathrm{~s}$, and $72^{\circ} \mathrm{C}$ for $1 \mathrm{~min}$. After the final cycle, the reaction was held at $72{ }^{\circ} \mathrm{C}$ for $5 \mathrm{~min}$, followed by $6^{\circ} \mathrm{C}$. The Curtovirus sp.-positive samples were identified using primers BCTV2-F and BCTV2-R designed for amplification of a 496-bp fragment of the coat protein gene, a region genetically conserved among BCTV strains. Strainspecific primer sets for the replication-associated protein (Rep) gene were used in the PCR assays: BSCTV-C1 2315F and BSCTV-C1 2740R for the Svr strain (region amplified matches a 426-bp segment from GenBank accession U02311); BMCTV-C1 2213F and BMCTV-C1 2609R for the Wor-like strains (region amplified matches a 397-bp segment from GenBank accession AY134867); and BCTV-C1 2097F and BCTV-C1 2387R for the CA/Logan strain (region amplified matches a 291-bp segment from GenBank accession AF379637). Amplification products were analyzed by agarose gel electrophoresis $(1.8 \%$ [wt/vol] supplemented with ethidium bromide at $0.01 \mathrm{mg} / \mathrm{ml}$ in Tris-borate EDTA [TBE] buffer [ $89 \mathrm{mM}$ Tris base, $89 \mathrm{mM}$ boric acid, and $2 \mathrm{mM}$ EDTA]). DNA from sugar beet sample CTS07-011 (contains strains CA/Logan, Svr, and Wor) served as a positive control (Strausbaugh et al. 2008). Reactions without template DNA served as negative controls. Comparisons between collections were conducted using a contingency test in SAS (version 9.4; SAS Institute Inc., Cary, NC) via the Proc Freq procedure with the $\chi^{2}$ statistic.

Genome sequencing. Whole-genome sequencing was conducted on 69 sugar beet isolates (Table 1), which were chosen to represent the widest geographic distribution for each strain for the production areas in which they were collected. All the sequenced isolates were from commercial sugar beet fields, except for seven isolates (CTS06-101, CTS06-102, CTS06-103, CTS06-104, CTS07-016, CTS14-1091, and CTS15-1188) collected from sugar beet plants infected with BCTV in the beet leafhopper insectary maintained by the Beet Sugar Development Foundation in Twin Falls, ID. DNA collection, quantification, and storage were as described in the previous section. Amplification of sequencing templates was performed in volumes of $40 \mu \mathrm{l}: 20 \mu \mathrm{l}$ of molecular-grade water (5 Prime Inc.), $8 \mu \mathrm{l}$ of $5 \times$ Green GoTaq buffer ( $\mathrm{pH} 8.5$ with $7.5 \mathrm{mM} \mathrm{MgCl}_{2}$; Promega Corp.), $1 \mu \mathrm{l}$ of $25 \mathrm{mM} \mathrm{MgCl} 2$ (Applied Biosystems), $0.75 \mu \mathrm{l}$ of $10 \mathrm{mM}$ dNTP (Promega Corp.), $4 \mu \mathrm{l}$ of $3 \mu \mathrm{M}$ each primer (Integrated DNA Technologies), $0.25 \mu \mathrm{l}$ of GoTaq Taq DNA polymerase (Promega Corp.), and $2 \mu \mathrm{l}$ (approximately $10 \mathrm{ng}$ ) of target DNA. The amplification consisted of $3 \mathrm{~min}$ at $95^{\circ} \mathrm{C}$; followed by 35 cycles of $95^{\circ} \mathrm{C}$ for $30 \mathrm{~s}, 55$ to $62^{\circ} \mathrm{C}$ (depending on primer pair) for $30 \mathrm{~s}$, and $72^{\circ} \mathrm{C}$ for $120 \mathrm{~s}$; which was followed by $5 \mathrm{~min}$ at $72^{\circ} \mathrm{C}$ and a holding temperature of $4^{\circ} \mathrm{C}$. The primary primer pairs RepQEW-For with CP450-Rev and V2Gen910-For with Rep2GQ-Rev, with overlapping sequences, were used to amplify the entire virus genome (Velasquez-Valle et al. 2012). For the hypervariable $\mathrm{C} 1$ region and for plants containing more than one BCTV strain, additional strainspecific primer combinations were utilized. Amplification products were analyzed by agarose gel electrophoresis $(1.8 \%$ [wt/vol] supplemented with ethidium bromide at $0.01 \mathrm{mg} / \mathrm{ml}$ in TBE $[89 \mathrm{mM}$ Tris base, $89 \mathrm{mM}$ boric acid, and $2 \mathrm{mM}$ EDTA]). Amplicons were sent to TACGen (Richmond, CA) for PCR cleanup (removes any excess dNTP and unincorporated primers) and were bidirectionally sequenced. Sanger sequencing was repeated to achieve $4 \times$ coverage of the entire genome and $8 \times$ coverage in the hypervariable $\mathrm{C} 1$ region.

Sequences were evaluated using BioEdit, version 7.1.3.0 (Hall 1999) and consensus sequences for each isolate were generated and deposited in GenBank (Table 1). To apply strain demarcation criteria established for BCTV based on sequence identity (Varsani et al. 2014a), sequences were aligned using MUSCLE (Edgar 2004) and compared via SDT v1.2 (Muhire et al. 2014). To graphically illustrate inferred evolutionary history, isolate sequences were compared with BCTV accessions from GenBank. DNA sequences were aligned using ClustalX Ver. 2.0 (Larkin et al. 2007). Using MEGA 7.0.14 
(Kumar et al. 2016), the TN93+G+I model (Tamura and Nei 1993) was determined to be the substitution model that best fit the data according to the Bayesian Information Criterion. Using this model, an evolutionary analysis was conducted by the maximumlikelihood method with MEGA 7.0.14. An initial search (two replicates) was used to estimate the model parameters. The parameters were then fixed for a bootstrap analysis of 1,000 replicates. The maximum-parsimony analysis was performed using PAUP 4.0b10 with the heuristic search, simple taxon addition sequences, tree bisection-reconnection branch swapping, and MaxTrees $=100$. Statistical support for the analyses was determined using bootstrap values for 1,000 replicates. The Bayesian phylogenetic analyses were conducted with MrBayes 3.2.5 (Ronquist and Huelsenbeck 2003), with searches run until the standard deviation of split frequencies declined $<0.01$. The analyses were conducted using the default priors (Fraser et al. 2010). The majority-rule consensus was then calculated after removing the first $25 \%$ of generations as burn-in. The trees were visualized using FigTree (ver. 1.4.2; Institute of Evolutionary Biology, University of Edinburgh, Edinburgh, UK). To graphically illustrate differences among strains, a dataset containing 31 isolates (including historical isolates and isolates representing the extremes in the phylogram clades) also was analyzed using SplitsTree 4.14.2 (Huson and Bryant 2006). Because there was a novel strain present in these analyses, this novel strain was compared with five isolates (AF379637, CA/Logan; JN817383, CO; KT583738, Leafhopper71 (LH71); U02311, Svr; and U56975, Wor; these represent the strains determined to be present on sugar beet plus strain LH71) to establish whether recombination occurred. The recombination analyses were conducted using default parameters for the following methods in RDP4 4.80 (Martin et al. 2015): RDP, GENECOV (Padidam et al. 1999), Bootscan (Martin et al. 2005), Maxchi (Smith 1992), Chimera (Posada and Crandall 2001), Siscan (Gibbs et al. 2000), and 3Seq (Boni et al. 2007). Potential recombination events detected with at least three of the seven methods $(P$ values $<0.05)$ and also supported by phylogenetic analyses were considered credible.

\section{Results}

Strain distribution. All samples included in collections to determine BCTV strain variation that produced BCTV-specific amplification products also produced amplification products with the BCTV coat protein primers (BCTV-F and -R). Among the 2006-to-2007 BCTV-positive samples, incidence of the Svr strain was 71 to $92 \%$ (78\% average for all areas; $87 \%$ average for Idaho and Oregon; Table 2). In contrast, the Svr strain was found in only 0 to $8 \%(2 \%$ average) of BCTV-positive samples in the 2012-to-2015 collection. The incidence of the CA/Logan strain in the 2006-to-2007 BCTVpositive samples was 0 to $14 \%$ (2\% average for all areas; $7 \%$ average for Idaho and Oregon; Table 2) whereas, in the 2012-to-2015 BCTVpositive samples, the range varied dramatically from 3 to $76 \%$ (30\% average), depending on the year. The incidence of the Wor-like strains in the 2006-to-2007 virus-positive samples was 21 to $100 \%$ (74\% average for all areas; $60 \%$ average for Idaho and Oregon; Table 2) whereas, in the 2012-to-2015 virus-positive samples, the range was 78 to $96 \%$ ( $87 \%$ average). Based on strain data in Table 2, the contingency test indicated that the 2006-to-2007 and 2012-to-2015 collections differed $\left(\chi^{2}=179, P<0.0001\right)$. The number of mixed infections during the 2006-to-2007 collection was 59\% whereas the number of mixed infections during the 2012-to-2015 collection was only $16 \%$.

Genome sequencing. In total, 69 BCTV genomes were sequenced and deposited in GenBank (KT276895 to KT276920 and KX867015 to KX867057; Table 1). When isolates were sequenced from samples positive for $\mathrm{CA} / \mathrm{Logan}$ and $\mathrm{Svr}$ based on the strain-specific primers (BCTV-C1 for CA/Logan and BSCTV-C1 for Svr), all genome sequences had the highest sequence identity with the same strain identified via the primers.

The genome sequences of the 22 isolates classified as Svr strain were all considered variants of the two historical Svr isolates (GenBank accessions U02311 and X97203) based on sequence identity, because they formed a single group with $>94 \%$ sequence identity among members in the Figure 1 pairwise comparison matrix. Evolutionary relationships among isolates in the maximum-likelihood phylogram in Figure 2 also placed all 22 Svr isolates into a single clade. However, within this clade, the Idaho and Oregon isolates were assigned to two subgroups (Fig. 2; top of the Svr clade), whereas the Colorado, Montana, and Wyoming isolates all fell into a separate subgroup (Fig. 2; bottom of the Svr clade). In the SplitsTree network analysis (Fig. 3), the Svr isolates formed a distinct cluster. Similar clusters were observed for other strains identified in the pairwise and evolutionary relationship analyses. There were also some evolutionary relationships suggested between the Svr isolates and the CA/Logan, PeCT, and SpCT isolates, because these isolates share the same main branch in Figure 2. The SplitsTree network analysis also connected all four of these strains as well.

The $11 \mathrm{CA} / \mathrm{Logan}$ sequences were considered variants of the two historical CA/Logan strains (GenBank accessions AF379637 and M24597.2) (Hormuzdi and Bisaro 1993; Stanley et al. 1986) based on sequence identity, because they formed a single group with $>94 \%$ sequence identity in the Figure 1 pairwise matrix. Evolutionary relationships in the phylogram in Figure 2 placed the CA/Logan isolates into a single clade.

When 36 genomes were sequenced from samples identified by the BMCTV-C1 Wor primers, $56 \%$ of the genomes were found to be the CO strain, whereas $39 \%$ were Wor and $5 \%$ were a novel, previously undescribed strain designated Kimberly1 (Kim1). The designations for these strain identifications were all supported by the pairwise identity matrix (Fig. 1), evolutionary relationships (Fig. 2), and network analysis (Fig. 3). Based on the phylogram, there were some evolutionary relationships between the CO, Mld, Wor, and PeYD strains, because they all share a node. The network analysis also placed these same four strains together at one end of the network. Based on the pairwise identity matrix, there was some overlap in sequence identity between a number of the $\mathrm{CO}$ and Wor strains. The 17 $\mathrm{CO}$ isolates that shared considerable sequence identity with Wor strains were from Idaho or Oregon, whereas the Idaho $\mathrm{CO}$ isolate KT276898 was similar to the California CO isolates. Among the $18 \mathrm{CO}$ isolates that had lower sequence identity with Wor, 15 were California isolates whereas the others were from Colorado or Nebraska. Phylogenetic analyses placed CO and Wor strains on a common node but split the $\mathrm{CO}$ and Wor isolates similar to the sequence identity matrix (Fig. 2). However, the two Idaho and Oregon CO isolates from 2007 (KT276898) and 2008 (KU892790) split off with the California $\mathrm{CO}$ isolates, whereas all of the more recently (2013 to 2015) collected CO isolates fell into a separate clade.

The two Kim1 isolates (from Idaho and Colorado) were most closely related to the LH71 strain (Chen and Gilbertson 2011, 2016) based on the pairwise identity matrix, phylogram, and network analysis. The distance results in Figure 4 from the RDP4 software also indicate that LH71 was closely related to Kim1. When comparing the Kim1 isolates versus the five reference isolates with the RDP4 software, the Kim1 isolate CTS06-056 (KT276896) was determined to be a potential recombinant with support from all seven methods. The results indicated evidence for the same recombination event to have occurred in Kim1 isolate CTS06-076 (KT276897) as well. The major parent was Wor (U56975), with $97.5 \%$ similarity and breakpoints at 1 to 1,633 and 3073 to 3092 . The minor parent was Svr (U02311), with $95.4 \%$ similarity and breakpoints at 1,634 to 3072 (Fig. 4).

\section{Discussion}

Data from the survey comparisons were the first evidence of a strain shift in sugar beet because $78 \%$ of the virus-positive sugar beet samples from the 2006-to-2007 collection were infected with the Svr strain (87\% for Idaho and Oregon samples alone) and 59\% of the plants had a mixed BCTV infection, whereas only $2 \%$ were positive for the Svr strain in the 2012-to-2015 collection and only $16 \%$ of the plants had a mixed infection. Sequencing the genomes of 22 samples positive for the Svr strain confirmed that the species-specific primers for Svr were accurate and reliably detected this strain. However, 39 genome sequences from the Wor-like primer-positive samples 
identified three strains with the following percentages: $56 \% \mathrm{CO}, 39 \%$ Wor, and 5\% Kim1, the latter a novel strain identified and genetically characterized in this study. When BCTV strains found in beet leafhoppers were investigated from northeastern Oregon from 2007 to 2008 (Rondon et al. 2016), two of the isolates (accessions KU892789 and KU892791) resembled the Wor strain and one was similar to CO (KU892790) (Fig. 2). This complement of strains was similar to that found in the sugar-beet-growing area of southern Idaho and southeastern Oregon, where $\mathrm{CO}$ and Wor have become the dominant BCTV strains.

In California tomato, there was also a transition in the most prevalent BCTV strains. The Svr and Wor strains predominated from the

Table 1. Source of the 111 Beet curly top virus (BCTV) isolates and sequences utilized in the phylogenetic analyses

\begin{tabular}{|c|c|c|c|c|c|c|}
\hline Isolate identification & GenBank accession & Strain $^{\mathbf{a}}$ & Year & Host & Country & State \\
\hline \multicolumn{7}{|l|}{ This study } \\
\hline CTS06-011 & KX867015 & $\mathrm{CO}$ & 2006 & Beta vulgaris & United States & Nebraska \\
\hline CTS06-012S & KX867016 & Svr & 2006 & B. vulgaris & United States & Colorado \\
\hline CTS06-012W & KX867017 & Wor & 2006 & B. vulgaris & United States & Colorado \\
\hline CTS06-013 & KX867018 & $\mathrm{CO}$ & 2006 & B. vulgaris & United States & Colorado \\
\hline CTS06-014 & KT276904 & Svr & 2006 & B. vulgaris & United States & Idaho \\
\hline CTS06-016 & KT276905 & Svr & 2006 & B. vulgaris & United States & Idaho \\
\hline CTS06-017 & KT276906 & Svr & 2006 & B. vulgaris & United States & Idaho \\
\hline CTS06-021 & KX867019 & Svr & 2006 & B. vulgaris & United States & Idaho \\
\hline CTS06-034 & KT276907 & Svr & 2006 & B. vulgaris & United States & Oregon \\
\hline CTS06-053 & KT276895 & $\mathrm{CO}$ & 2006 & B. vulgaris & United States & Colorado \\
\hline CTS06-056 & KT276896 & Kim1 & 2006 & B. vulgaris & United States & Idaho \\
\hline CTS06-060 & KX867020 & Wor & 2006 & B. vulgaris & United States & Colorado \\
\hline CTS06-065 & KX867021 & Wor & 2006 & B. vulgaris & United States & Colorado \\
\hline CTS06-066 & KX867022 & $\mathrm{CO}$ & 2006 & B. vulgaris & United States & Colorado \\
\hline CTS06-068 & KX867023 & Wor & 2006 & B. vulgaris & United States & Colorado \\
\hline CTS06-070 & KX867024 & Wor & 2006 & B. vulgaris & United States & Colorado \\
\hline CTS06-073 & KX867025 & Wor & 2006 & B. vulgaris & United States & Colorado \\
\hline CTS06-076 & KT276897 & Kim1 & 2006 & B. vulgaris & United States & Colorado \\
\hline CTS06-078 & KX867026 & Svr & 2006 & B. vulgaris & United States & Wyoming \\
\hline CTS06-081 & KX867027 & Svr & 2006 & B. vulgaris & United States & Wyoming \\
\hline CTS06-091 & KX867028 & Svr & 2006 & B. vulgaris & United States & Montana \\
\hline CTS06-101 & KX867029 & CA/Logan & 2006 & B. vulgaris & United States & Idaho \\
\hline CTS06-102 & KX867030 & CA/Logan & 2006 & B. vulgaris & United States & Idaho \\
\hline CTS06-103 & KX867031 & CA/Logan & 2006 & B. vulgaris & United States & Idaho \\
\hline CTS06-104 & KX867032 & CA/Logan & 2006 & B. vulgaris & United States & Idaho \\
\hline CTS06-110 & KX867033 & CA/Logan & 2006 & B. vulgaris & United States & Idaho \\
\hline CTS06-111 & KX867034 & CA/Logan & 2006 & B. vulgaris & United States & Idaho \\
\hline CTS07-016 & KX867035 & CA/Logan & 2007 & B. vulgaris & United States & Idaho \\
\hline CTS07-019 & KT276898 & $\mathrm{CO}$ & 2007 & B. vulgaris & United States & Idaho \\
\hline CTS07-020 & KT276902 & Wor & 2007 & B. vulgaris & United States & Idaho \\
\hline CTS07-021 & KT276903 & Wor & 2007 & B. vulgaris & United States & Idaho \\
\hline CTS07-023 & KT276908 & Svr & 2007 & B. vulgaris & United States & Wyoming \\
\hline CTS07-036 & KX867036 & Svr & 2007 & B. vulgaris & United States & Wyoming \\
\hline CTS07-043 & KX867037 & Svr & 2007 & B. vulgaris & United States & Wyoming \\
\hline CTS07-046 & KT276909 & Svr & 2007 & B. vulgaris & United States & Idaho \\
\hline CTS07-048 & KT276910 & Svr & 2007 & B. vulgaris & United States & Oregon \\
\hline CTS07-053 & KT276911 & Svr & 2007 & B. vulgaris & United States & Idaho \\
\hline CTS07-056 & KT276912 & Svr & 2007 & B. vulgaris & United States & Idaho \\
\hline CTS07-057 & KT276913 & Svr & 2007 & B. vulgaris & United States & Idaho \\
\hline CTS07-059 & KT276914 & Svr & 2007 & B. vulgaris & United States & Idaho \\
\hline CTS07-088 & KT276915 & Svr & 2007 & B. vulgaris & United States & Idaho \\
\hline CTS07-091 & KX867038 & Wor & 2007 & B. vulgaris & United States & Colorado \\
\hline CTS07-096 & KT276916 & Svr & 2007 & B. vulgaris & United States & Montana \\
\hline CTS07-101 & KT276917 & Svr & 2007 & B. vulgaris & United States & Wyoming \\
\hline CTS07-129 & KT276918 & Svr & 2007 & B. vulgaris & United States & Montana \\
\hline CTS12-024 & KX867039 & Wor & 2012 & B. vulgaris & United States & Idaho \\
\hline CTS13-005 & KX867040 & CA/Logan & 2013 & B. vulgaris & United States & Idaho \\
\hline CTS13-028 & KX867041 & CA/Logan & 2013 & B. vulgaris & United States & Idaho \\
\hline CTS13-060 & KX867042 & $\mathrm{CO}$ & 2013 & B. vulgaris & United States & Idaho \\
\hline CTS13-062 & KX867043 & $\mathrm{CO}$ & 2013 & B. vulgaris & United States & Idaho \\
\hline CTS13-063 & KX867044 & $\mathrm{CO}$ & 2013 & B. vulgaris & United States & Idaho \\
\hline CTS14-001 & KT276899 & $\mathrm{CO}$ & 2014 & B. vulgaris & United States & Idaho \\
\hline CTS14-014 & KT276900 & $\mathrm{CO}$ & 2014 & B. vulgaris & United States & Idaho \\
\hline CTS14-015 & KX867045 & Wor & 2014 & B. vulgaris & United States & Idaho \\
\hline CTS14-024 & KT276901 & $\mathrm{CO}$ & 2014 & B. vulgaris & United States & Idaho \\
\hline
\end{tabular}

a BCTV strains California/Logan (CA/Logan), Colorado (CO), Kimberly1 (Kim1), Mild (Mld), Leafhopper 71 (LH71), Pepper curly top (PeCT), Pepper yellow dwarf (PeYD), Severe (Svr; formerly CFH), Severe pepper (SvrPep), Spinach curly top (SpCT), and Worland (Wor). 
mid-1990s during the first formal survey of the molecular era (Stenger and Ostrow 1996), through subsequent surveys as late as 2008 (Chen et al. 2010). In contrast, strain evaluations during the 2013 California outbreak, when upward of $\$ 100$ million was lost (Gordon 2014), suggest the emergence of new variants displacing the older strains. The earliest sequenced $\mathrm{CO}$ isolates from Idaho sugar beet in 2007 (KT276898) and a leafhopper in Oregon in 2008 (KU892790) fall in the same clade as the CO isolates associated with the California curly top outbreak in tomato. The CO isolates collected more recently (2013 to 2015) in sugar beet from Idaho and Oregon appear to have diverged and were distributed into a different clade within the phylogram.

Table 1. (continued from preceding page)

\begin{tabular}{|c|c|c|c|c|c|c|}
\hline Isolate identification & GenBank accession & Strain $^{\mathbf{a}}$ & Year & Host & Country & State \\
\hline CTS14-054 & KX867046 & $\mathrm{CO}$ & 2014 & B. vulgaris & United States & Idaho \\
\hline CTS14-067 & KX867047 & $\mathrm{CO}$ & 2014 & B. vulgaris & United States & Idaho \\
\hline CTS14-070 & KX867048 & $\mathrm{CO}$ & 2014 & B. vulgaris & United States & Oregon \\
\hline CTS14-071 & KX867049 & $\mathrm{CO}$ & 2014 & B. vulgaris & United States & Oregon \\
\hline CTS14-124 & KX867050 & $\mathrm{CO}$ & 2014 & B. vulgaris & United States & Idaho \\
\hline CTS14-1091 & KT276919 & CA/Logan & 2014 & B. vulgaris & United States & Idaho \\
\hline CTS15-001 & KX867051 & $\mathrm{CO}$ & 2015 & B. vulgaris & United States & Idaho \\
\hline CTS15-045 & KX867052 & $\mathrm{CO}$ & 2015 & B. vulgaris & United States & Idaho \\
\hline CTS15-086 & KX867053 & Wor & 2015 & B. vulgaris & United States & Idaho \\
\hline CTS15-091 & KX867054 & Wor & 2015 & B. vulgaris & United States & Idaho \\
\hline CTS15-095 & KX867055 & Wor & 2015 & B. vulgaris & United States & Idaho \\
\hline CTS15-113 & KX867056 & $\mathrm{CO}$ & 2015 & B. vulgaris & United States & Idaho \\
\hline CTS15-149 & KX867057 & $\mathrm{CO}$ & 2015 & B. vulgaris & United States & Idaho \\
\hline CTS15-1188 & KT276920 & CA/Logan & 2015 & B. vulgaris & United States & Idaho \\
\hline \multicolumn{7}{|l|}{ Other studies } \\
\hline BCTV-I & X97203 & Svr & 1986 & B. vulgaris & Iran & $\ldots$ \\
\hline BCTV-2007 & KU892789 & Wor & 2007 & Circulifer tenellus & United States & Oregon \\
\hline BCTV-2008 & KU892790 & $\mathrm{CO}$ & 2008 & C. tenellus & United States & Oregon \\
\hline BCTV-2009 & KU892791 & Wor & 2009 & C. tenellus & United States & Oregon \\
\hline BMCTV & EU193175 & Mld & 2006 & Capsicum аппиит & Mexico & $\ldots$ \\
\hline BV3 & JX487184 & PeCT & 2009 & Solanum lycopersicum & United States & California \\
\hline B4-2 & KT583729 & $\mathrm{CO}$ & 2013 & B. vulgaris & United States & California \\
\hline $\mathrm{Cal}$ & M24597.2 & CA/Logan & 1985 & B. vulgaris & United States & California \\
\hline $\mathrm{CFH}$ & U02311 & Svr & 1990 & B. vulgaris & United States & $\ldots$ \\
\hline FB1-18 & KT583732 & $\mathrm{CO}$ & 2013 & B. vulgaris & United States & $\ldots$ \\
\hline FM3-1-10 & KT583733 & $\mathrm{CO}$ & 2013 & Cucumis melo & United States & California \\
\hline FM4-3-3 & KT583734 & $\mathrm{CO}$ & 2013 & C. melo & United States & California \\
\hline FP8-9 & KT583735 & LH71 & 2013 & S. lycopersicum & United States & California \\
\hline F1-1-2 & KT583728 & $\mathrm{CO}$ & 2013 & S. lycopersicum & United States & California \\
\hline F1-1-3 & KT583730 & $\mathrm{CO}$ & 2013 & S. lycopersicum & United States & California \\
\hline F1-2-25 & KT583731 & LH71 & 2013 & S. lycopersicum & United States & California \\
\hline KB1-1 & KT583739 & $\mathrm{CO}$ & 2013 & S. lycopersicum & United States & California \\
\hline $\mathrm{K} 1-2$ & KT583736 & $\mathrm{CO}$ & 2013 & S. lycopersicum & United States & California \\
\hline $\mathrm{K} 2-10$ & KT583737 & $\mathrm{CO}$ & 2013 & S. lycopersicum & United States & California \\
\hline $\mathrm{K} 5$ & KT583738 & LH71 & 2013 & S. lycopersicum & United States & California \\
\hline LH7-3-5 & KT583740 & LH71 & 2013 & Circulifer tenellus & United States & California \\
\hline LH71 & KT583748 & LH71 & 2010 & C. tenellus & United States & California \\
\hline Logan & AF379637 & CA/Logan & 1976 & B. vulgaris & United States & Utah \\
\hline M1-1-1 & KT583741 & $\mathrm{CO}$ & 2013 & S. lycopersicum & United States & California \\
\hline M1-3-8 & KT583742 & LH71 & 2013 & S. lycopersicum & United States & California \\
\hline M2-4 & KT583743 & $\mathrm{CO}$ & 2013 & S. lycopersicum & United States & California \\
\hline MXP24-07 & HQ214016 & Mld & 2007 & Capsicum аппиит & Mexico & $\ldots$ \\
\hline New Mexico & EF501977 & $\mathrm{PeCT}$ & 2005 & C. аппиит & United States & New Mexico \\
\hline pCO-95-6-31 & JN817383 & $\mathrm{CO}$ & 1995 & B. vulgaris & United States & Colorado \\
\hline PeYD & EU921828 & PeYD & 2007 & C. аппиит & United States & New Mexico \\
\hline SLP1 & EU586260 & Mld & 2007 & C. аппиит & Mexico & $\ldots$ \\
\hline SLP2 & EU586261 & Mld & 2007 & C. аппиит & Mexico & $\ldots$ \\
\hline SJ & KT583749 & SpCT & 2014 & S. lycopersicum & United States & California \\
\hline SJ-Y1-37 & KT583746 & Wor & 2013 & Cucurbita sp. & United States & California \\
\hline SJ1-2 & KT583744 & $\mathrm{CO}$ & 2013 & S. lycopersicum & United States & California \\
\hline SJ2-1 & KT583745 & LH71 & 2013 & S. lycopersicum & United States & California \\
\hline SK1-2 & KT583747 & $\mathrm{CO}$ & 2013 & S. lycopersicum & United States & California \\
\hline $\mathrm{Sp} 3$ & AY548948 & $\mathrm{SpCT}$ & 1996 & Spinacia oleracea & United States & $\ldots$ \\
\hline LRME27607 & FJ545686 & SvrPep & 2001 & C. аппиит & United States & New Mexico \\
\hline Worland & U56975 & Wor & 1996 & Capsella bursa-pastoris & United States & Wyoming \\
\hline Worland4 & AY134867 & Wor & 2002 & B. vulgaris & United States & $\ldots$ \\
\hline $8-10$ & HQ634913 & Mld & 2010 & Phaseolus vulgaris & Mexico & $\ldots$ \\
\hline
\end{tabular}


Based on the guidelines published by Varsani et al. (2014a), there are two previously unidentified strains among the sequences in GenBank. Genome sequences for the isolates CTS06-056 and CTS06-076 (GenBank accessions KT276896 and KT276897, respectively) submitted as part of this study have less than $94 \%$ sequence identity with other strains (Fig. 1) and also fall into a separate group in the phylogenetic (Fig. 2) and network (Fig. 3) analyses. Consequently, these two isolates have been designated Kim1 (for Kimberly, ID, where the original isolate was collected) and are composed of 2,929 to 2,933 nucleotides with seven open reading frames encoding proteins homologous to those of other curtoviruses. Based on these criteria, the beet leafhopper isolates from California (GenBank accessions KT583731, KT583735, KT583738, KT583740, KT583742, KT583745, and KT583748) form another distinct strain, designated LH71 (Chen and Gilbertson 2011, 2016). With the addition of these two strains, this is the first publication to establish 11 recognized strains of BCTV based on current accepted taxonomic criteria (Varsani et al. 2014a).

The sequence analysis of the Idaho and Oregon isolates led to the addition of 69 genome accessions in GenBank, and has identified the predominant strains present in sugar beet during the period during which collections occurred. BCTV, like other viruses, is a collection of dominant and less common strains for which emergence and dominance in a host likely depend on a number of factors. Thus, variants present at very low frequency may not have been identified.

Evaluation of the 111 BCTV genomes available on GenBank assists in clarification of the evolutionary relationships among known BCTV strains. With support from three phylogenetic methods, the maximum-likelihood tree showed the CO, Mld, Wor, and PeYD strains shared a common node, providing evidence for an evolutionary relationship among these strains. The network analysis also demonstrated that these strains are not as divergent from one another as are the other isolates. When evolutionary relationships and recombination events for the CO, Mld, Wor, and PeYD strains were evaluated by Varsani et al. (2014a), similar relationships were established. Similarly, Svr, SpCT, PeCT, and CA/Logan were connected by a common node, whereas Kim1 and LH71 were on other nodes. These nodes were connected at another node, providing evidence for an evolutionary relationship. Similarities in the network analysis among these strains also supported these relationships. Recombination analysis suggests that Kim1 is a recombinant, with the major parent being Wor and the minor parent being Svr. When evolutionary relationships and recombination events for the Svr, SpCT, $\mathrm{PeCT}$, and CA/Logan strains were evaluated by Varsani et al. (2014a), similar relationships were evident.

The comparisons between the 2006-to-2007 and 2012-to-2015 collections provide evidence of a reduction in prevalence of the
Svr strain and the number of mixed infections (positive for more than one primer set). The reduction in mixed infections appears to be a result of the reduction in the incidence of the Svr strain. However, these reductions between collections do not necessarily reflect changes in symptom severity on sugar beet. Most of the sugar beet plants sampled between 2012 and 2015 exhibited relatively mild symptoms (slight upward leaf rolling, vein thickening, and stunting). The mild symptoms could have resulted from infection with a mildly virulent strain of the virus, infection after plants achieve significant size (Wintermantel and Kaffka 2006), or both. Historically the Svr and $\mathrm{CA} /$ Logan strains have been some of the most virulent on sugar beet and that status may not have changed. However, a significant change in crop management also occurred when neonicotinoid seed treatments became fully labeled for use on sugar beet in 2008. Sugar beet growers planting in the spring in semiarid growing areas rapidly adopted the seed treatments to supplement the low to moderate curly top resistance in commercial cultivars (Panella et al. 2014). Therefore, beet leafhoppers coming off the desert in the spring in Idaho

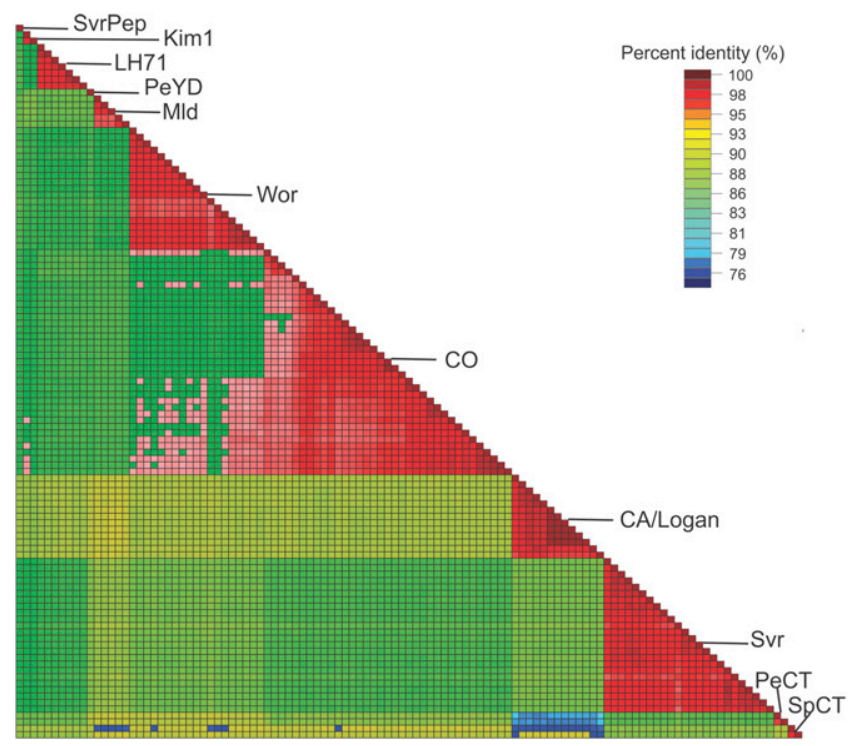

Fig. 1. Two-dimensional pairwise identity color matrix with pairwise identities was aligned with MUSCLE and calculated using SDT v1.2 to compare 111 Beet curly top virus (BCTV) genomes. BCTV strains are as follows: CA/Logan $=$ California/ Logan, $\mathrm{CO}=$ Colorado, Kim1 $=$ Kimberly1, LH71 $=$ Leafhopper 71, Mld = Mild, $\mathrm{PeCT}=$ Pepper curly top, $\mathrm{PeYD}=$ Pepper yellow dwarf, Svr $=$ Severe (formerly $\mathrm{CFH})$, SvrPep $=$ Severe pepper, SpCT $=$ Spinach curly top , and Wor $=$ Worland.

Table 2. Beet curly top virus (BCTV) strains associated with 406 sugar beet samples collected from 2012 to 2015 in Oregon and Idaho and compared with 246 samples from a 2006-to-2007 collection

\begin{tabular}{|c|c|c|c|c|c|}
\hline \multirow[b]{2}{*}{ Yearb } & \multirow[b]{2}{*}{ Sample number } & \multirow[b]{2}{*}{ Coat protein $(\%)^{\mathrm{c}}$} & \multicolumn{3}{|c|}{ BCTV strain $(\%)^{\mathrm{a}}$} \\
\hline & & & Svr & CA/Logan & Wor-like \\
\hline 2006 (all areas) & 101 & 98 & 71 & 5 & 95 \\
\hline 2006 (ID, OR) & 35 & 93 & 82 & 14 & 100 \\
\hline 2007 (all areas) & 145 & 89 & 84 & 0 & 53 \\
\hline 2007 (ID, OR) & 33 & 73 & 92 & 0 & 21 \\
\hline 2012 & 50 & 56 & 0 & 29 & 79 \\
\hline 2013 & 72 & 71 & 8 & 76 & 78 \\
\hline 2014 & 131 & 97 & 2 & 13 & 95 \\
\hline 2015 & 153 & 67 & 0 & 3 & 96 \\
\hline
\end{tabular}

${ }^{a}$ Sugar beet leaf samples positive for coat protein (primers BCTV2-F and -R) were evaluated further with BCTV strain-specific primers to determine the percentage of samples positive for the Severe (Svr; formerly CFH; primers BSCTV-C1 2315F and 2740F) and California/Logan (CA/Logan; primers BCTVC1 2097F and 2387R) strains. Worland (Wor)-like primers (BMCTV-C1 2213F and 2609R) detected the Colorado, Kimberly1, and Wor strains.

${ }^{\mathrm{b}}$ Sugar beet leaf samples symptomatic for BCTV were collected from the Idaho and Oregon production area from 2012 to 2015 . These samples were compared with those collected previously from throughout the western United States sugar beet production areas in 2006 and 2007 (Strausbaugh et al. 2008), designated as "all areas." The subset of data from 2006 and 2007 that represented the Idaho and Oregon production area is designated "ID, OR". The 2006 and 2007 data were published previously (Strausbaugh et al. 2008) in a different format and summarized here to facilitate easy comparison with current data sets.

c Percentage of samples positive with the primers specific for the BCTV coat protein 


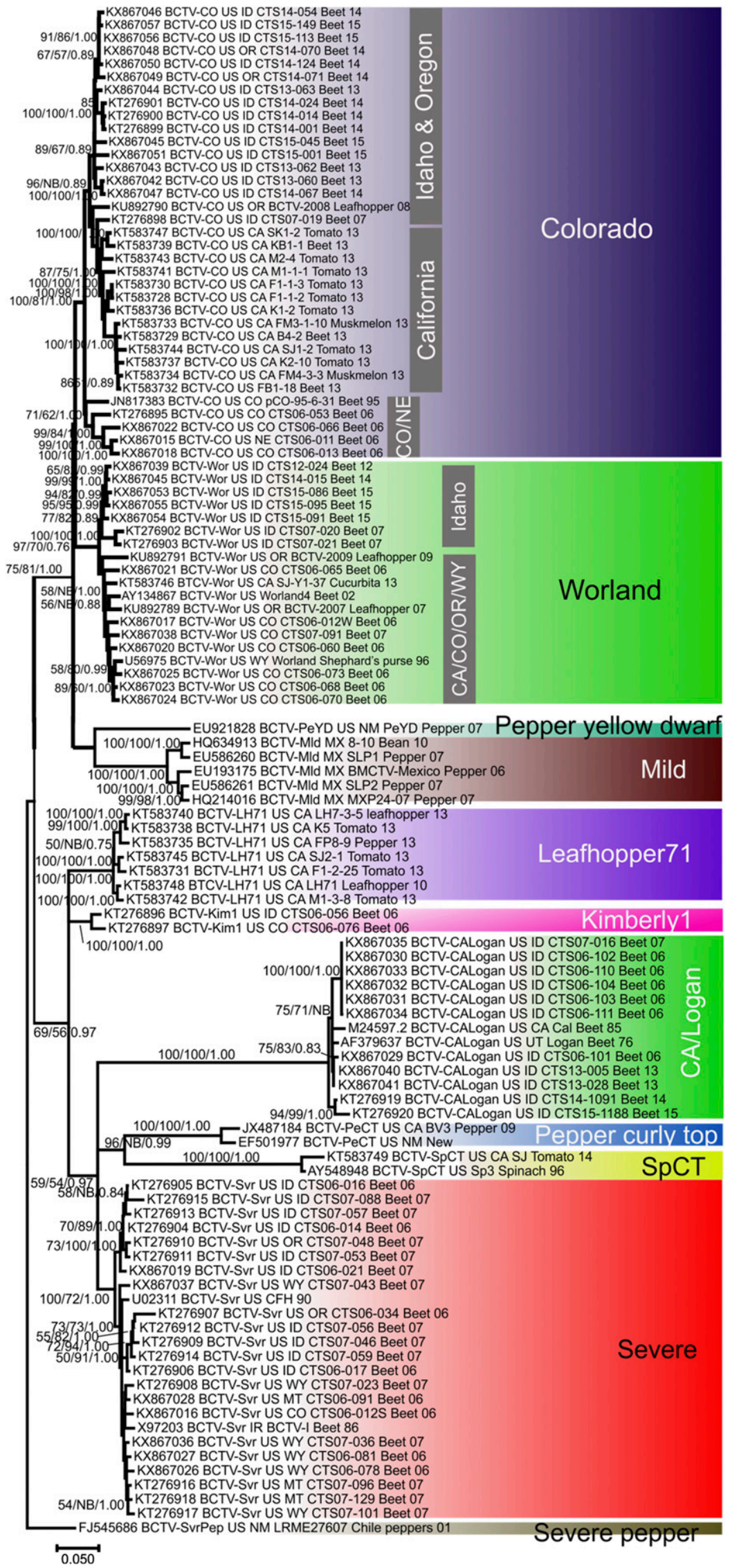

Fig. 2. Phylogenetic relationships among 111 Beet curly top virus genomes were compared among isolates and strains collected from Idaho, Oregon, a 2006 -to-2007 collection, and sequences deposited in GenBank. Numbers on the nodes of the maximum-likelihood (ML) tree represent the statistical support for ML (1,000 replicates, left number), maximum parsimony (MP; 1,000 bootstrap replicates, middle number), and Bayesian method (posterior probabilities, right number). NB = no branch. The tree is drawn to scale, with the branch lengths measured in the number of substitutions per site. Isolates are identified by GenBank accession number followed by strain identification (strain designation, country and state of collection, isolate identification, host, and year of collection). 
were likely limited in their ability to feed and transmit BCTV in the sugar beet crop for at least the first two and a half months of the growing season as a result of the neonicotinoid seed treatment. The treatment has been shown to last at least 77 days (Strausbaugh et al.

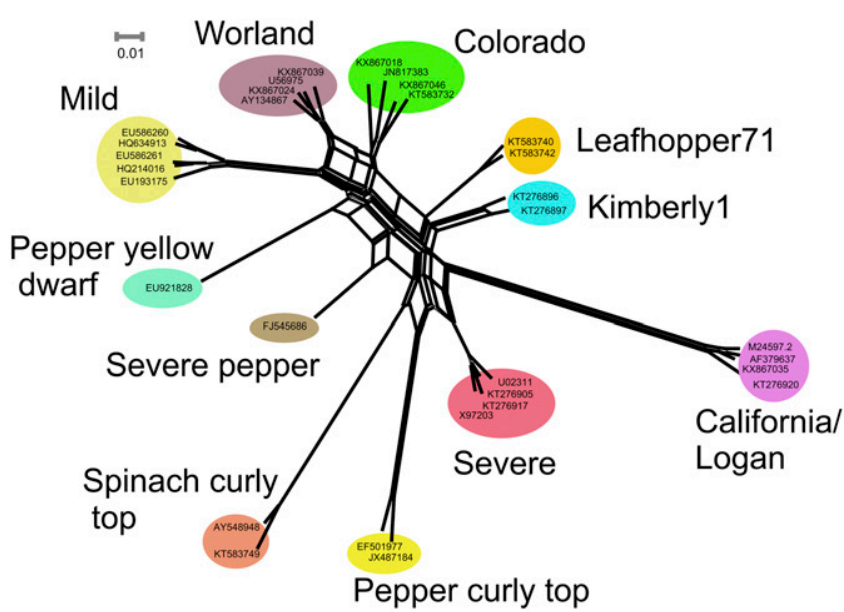

Fig. 3. Median-joining network created using SplitsTree4 ver. 4.13 .1 was utilized to identify differences among 31 Beet curly top virus (BCTV) isolate genomes (designated by their GenBank accession number) representing the 11 BCTV strains. The figure graphically shows the extent of differences among isolates and strains rather than phylogenetic relationships, and takes into account not only nucleotide changes but also gaps in sequence alignment. Isolates selected for this analysis were chosen because they represent historically significant isolates or isolates that were the most divergent in the clades associated with each strain in the phylogenetic analyses.
2016). Therefore, beet leafhoppers surviving in the initial migration from the desert would have to survive on alternate host plants such as common bean or weeds. Preliminary data suggest that mild strains are more effective at establishing in bean and some weed hosts than the Svr strain (Chen and Gilbertson 2009; Wintermantel 2011). These alternate hosts may have favored the $\mathrm{CO}$ and Wor strains over the Svr strain, because beet leafhoppers moving to sugar beet might not have been successful at transmitting BCTV until the second generation of beet leafhoppers developed and migrated to sugar beet plants. BCTV transmission is known to be affected by the acquisition host and the ability of the host to maintain high virus titer because BCTV does not replicate in the vector (Chen and Gilbertson 2009; Soto and Gilbertson 2003). Another factor that could have driven a BCTV strain change would be the addition of strain-specific resistance in commercial sugar beet cultivars. Recently, evidence for strain-specific differences in response to sugar beet resistance sources was provided (Montazeri et al. 2016); however, the presence of specific resistance genes or combinations of genes in commercial sugar beet cultivars is not publicly known. Therefore it remains difficult to determine which genes are most effective against specific BCTV strains. Changes in virulence of isolates classified genetically within specific strains on specific host plants, including sugar beet, may have occurred as well but insufficient information is available at this time.

As mentioned above, a large portion of the sugar beet plants sampled between 2012 and 2015 exhibited relatively mild symptoms. However, these mild symptoms were difficult to distinguish from sugar beet plants that were poorly irrigated (wind likely shifted the irrigation sprinkler pattern), because plants that had water deficiencies during the growing season were also stunted and had curled leaves. Thus, the lower percentage of plants positive for the coat protein primers likely reflects the sampling of poorly irrigated plants rather than plants containing a virus variant with a different coat protein.

\section{BCTV genome}
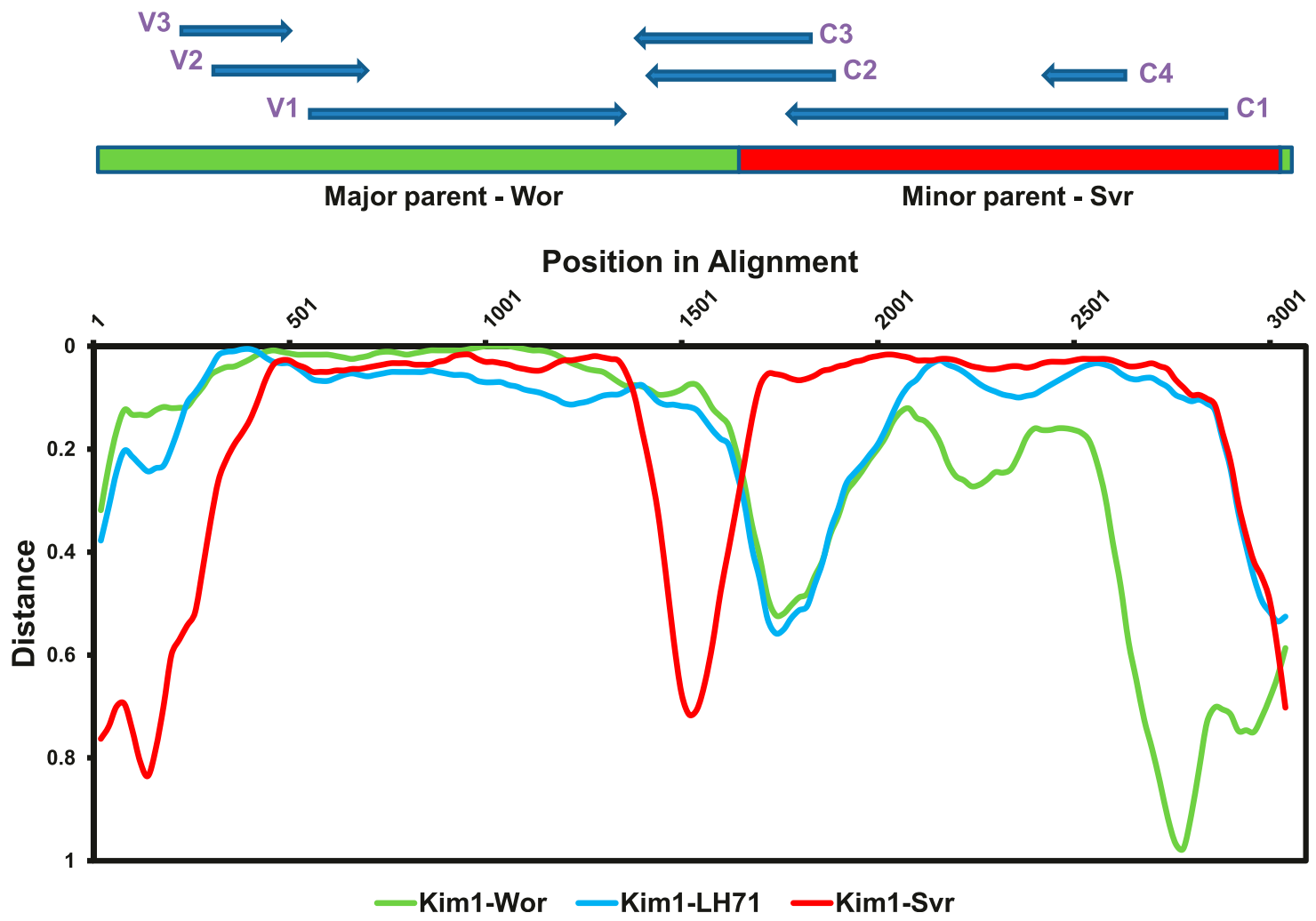

Fig. 4. Distance plot based on the aligned Beet curly top virus (BCTV) genomes of isolates CTS06-056, for the potential recombinant strain Kimberly1 (Kim1; GenBank accession KT276896); Worland, for major parent strain Worland (Wor; U56975); CFH, for minor parent strain Severe (Svr; U02311); and K5, a strain closely related to Leafhopper 71 (LH71; KT583738). The $x$-axis represents the nucleotide position in the alignment and the $y$-axis represents the relative distance from the reference sequence Kim1 calculated using the Kimura model (Kimura 1980). Above the distance plot is a schematic diagram showing the BCTV genome with the gene positions coded in the virion-sense (V) and complementary (C) directions, along with a bar for the Kim1 strain indicating the homologous sequences present in the two parent strains Wor and Svr. 
The coat protein nucleotide sequence has historically been conserved among all the BCTV strains.

Prior to the 2006-to-2007 collection, the CA/Logan strain was widely perceived to have become very rare and possibly extinct in nature, because no isolates had been identified in many years (Chen et al. 2010; Creamer et al. 2005). The isolate was believed to exist primarily in laboratory collections. The 2006-to-2007 collection (Strausbaugh et al. 2008) demonstrated an average of $7 \%$ incidence of the CA/ Logan strain in sugar beet plants evaluated from the Idaho production area, whereas the current survey averaged $30 \%$ incidence of CA/Logan among plants evaluated from the same region. If any variants in the sequencing were under represented they may be of the CA/Logan strain because, of all strains, it was the most difficult to obtain the complete genome sequences of this strain using the overlapping primer approach. Furthermore, the 2006-to-2007 collection demonstrated that the few isolates of CA/Logan identified at that time were divergent from one another, supporting the longstanding belief that this strain had been present in the United States for many years and was likely influenced by geographic separation of isolates and locally influenced natural selection (Strausbaugh et al. 2008).

Although insecticide-based control using neonicotinoid seed treatments is quite effective in reducing BCTV incidence and severity, host resistance remains a primary control measure utilized by sugar beet producers for control of curly top (Strausbaugh et al. 2016). However, with new evidence suggesting that some sources of curly top resistance in sugar beet may be more effective against specific BCTV strains (Montazeri et al. 2016), monitoring and evaluating resistance sources against all strains is becoming increasingly important. New strains of BCTV can be expected to continually evolve in response to natural and manmade selection pressure. Screening on a regional basis may also be necessary due to geographic separation of different leafhopper populations and the BCTV isolates each transmits, as well as locally influenced host and environmental conditions.

\section{Acknowledgments}

These data support the objectives of the United States Department of AgricultureAgricultural Research Service CRIS projects 5368-21220-003-00D and 203822000-013-00D. We thank J. Reed for research contributions; the Amalgamated Sugar Co., LLC, Amalgamated Research, LLC, Beet Sugar Development Foundation, and Snake River sugar beet growers for their support; and D. C. Stenger and R. L. Gilbertson for their critical review of the manuscript and helpful suggestions.

\section{Literature Cited}

Ali, Z., Abulfaraj, A., Idris, A., Ali, S., Tashkandi, M., and Mahfouz, M. M. 2015. CRISPR/Cas9-mediated viral interference in plants. Genome Biol. 16:238.

Aregger, M., Borah, B. K., Seguin, J., Rajeswaran, R., Gubaeva, E. G., Zvereva, A. S., Windels, D., Vazquez, F., Blevins, T., Farinelli, L., and Pooggin, M. M. 2012. Primary and secondary siRNAs in geminivirus-induced gene silencing. PLoS Pathog. 8:e1002941.

Bach, J., and Jeske, H. 2014. Defective DNAs of Beet curly top virus from longterm survivor sugar beet plants. Virus Res. 183:89-94.

Baliji, S., Black, M. C., French, R., Stenger, D. C., and Sunter, G. 2004. Spinach curly top virus: A newly described Curtovirus species from southwest Texas with incongruent gene phylogenies. Phytopathology 94:772-779.

Bennett, C. W. 1971. The Curly Top Disease of Sugarbeet and Other Plants, Monogr. No. 7. American Phytopathological Society, St. Paul, MN.

Blickenstaff, C. C., and Traveller, D. 1979. Factors affecting curly top damage to sugarbeets and beans in southern Idaho, 1919-77. Science and Education Administration, Agricultural Reviews and Manuals, West. Ser, No. 8. United States Department of Agriculture-Agricultural Research Service, Oakland, CA.

Boni, M. F., Posada, D., and Feldman, M. W. 2007. An exact nonparametric method for inferring mosaic structure in sequence triplets. Genetics 176: 1035-1047.

Briddon, R. W., Heydarnejad, J., Khosrowfar, F., Massumi, H., Martin, D. P., and Varsani, A. 2010. Turnip curly top virus, a highly divergent geminivirus infecting turnip in Iran. Virus Res. 152:169-175.

Briddon, R. W., Stenger, D. C., Bedford, I. D., Stanley, J., Izadpanah, K., and Markham, P. G. 1998. Comparison of a beet curly top virus isolate originating from the old world with those from the new world. Eur. J. Plant Pathol. 104:77-84.

Chen, L., and Gilbertson, R. L. 2011. Evidence that recombination plays an important role in the evolution and emergence of new curotviruses (family Geminiviridae). (Abstr.). Phytopathology 101:S32.

Chen, L.-F., Brannigan, K., Clark, R., and Gilbertson, R. L. 2010. Characterization of curtoviruses associated with curly top disease of tomato in California and monitoring for these viruses in beet leafhoppers. Plant Dis. 94:99-108.
Chen, L.-F., and Gilbertson, R. L. 2009. Curtovirus-cucurbit interaction: Acquisition host plays a role in leafhopper transmission in a host-dependent manner. Phytopathology 99:101-108.

Chen, L.-F., and Gilbertson, R. L. 2016. Transmission of Curtoviruses (Beet curly top virus) by the beet leafhopper (Circulifer tenellus). Pages 243-262 in: VectorMediated Transmission of Plant Pathogens. J. K. Brown, ed. American Phytopathological Society, St. Paul, MN.

Chen, L.-F., Natwick, E., Cabrera, S., and Gilbertson, R. L. 2014. First report of curly top disease of basil caused by Beet severe curly top virus in California. Plant Dis. 98:286.

Chen, L.-F., Vivoda, E., and Gilbertson, R. L. 2011. Genetic diversity in curtoviruses: A highly divergent strain of Beet mild curly top virus associated with an outbreak of curly top disease in pepper in Mexico. Arch. Virol. 156:547-555.

Creamer, R., Hubble, H., and Lewis, A. 2005. Curtovirus infection in chile pepper in New Mexico. Plant Dis. 89:480-486.

Creamer, R., Luque-Williams, M., and Howo, M. 1996. Epidemiology and incidence of beet curly top geminivirus in naturally infected weed hosts. Plant Dis. 80: 533-535.

Edgar, R. C. 2004. MUSCLE: Multiple sequence alignment with high accuracy and high throughput. Nucleic Acids Res. 32:1792-1797.

Fraser, D. A. S., Reid, N., Marras, E., and Yi, G. Y. 2010. Default priors for Bayesian and frequentist inference. J. R. Stat. Soc. B 72:631-654.

Gharouni Kardani, S., Heydarnejad, J., Zakiaghl, M., Mehrvar, M., Kraberger, S., and Varsani, A. 2013. Diversity of Beet curly top Iran virus isolated from different hosts in Iran. Virus Genes 46:571-575.

Gibbs, M. J., Armstrong, J. S., and Gibbs, A. J. 2000. Sister-scanning: A Monte Carlo procedure for assessing signals in recombinant sequences. Bioinformatics 16:573-582.

Gillen, A. M., Strausbaugh, C. A., and Tindall, K. V. 2008. Evaluation of Beta corolliflora for resistance to curly top in Idaho. J. Sugar Beet Res. 45:99-118.

Golenberg, E. M., Sather, D. N., Hancock, L. C., Buckley, K. J., Villafranco, N. M., and Bisaro, D. M. 2009. Development of a gene silencing DNA vector derived from a broadhost range geminivirus. Plant Methods 5:9.

Gordon, R. 2014. Beet curly top virus is an unpredictable disease. Am. Veg. Grow. September: 23-26. Online: http://www.growingproduce.com/crop-protection/ disease-control/beet-curly-top-virus-is-an-unpredictable-disease/

Hall, T. 1999. BioEdit: A user-friendly biological science sequence alignment editor and analysis program for Windows 95/98/NT. Nucleic Acids Symp. Ser. 41:95-98.

Harveson, R. M. 2015. Beet curly top: America's first serious disease of sugar beets. Online publication. APS Features. doi:10.1094/APSFeature-2015-02

Hernandez, C., and Brown, J. K. 2010. First report of a new curtovirus species, Spinach severe curly top virus, in commercial spinach plants (Spinacia oleracea) from south-central Arizona. Plant Dis. 94:917.

Hernández-Zepeda, C., Varsani, A., and Brown, J. K. 2013. Intergenic recombination between a new, spinach-infecting curtovirus and a new geminivirus belonging to the genus Becurtovirus: First new world exemplar. Arch. Virol. 158:2245-2254.

Heydarnejad, J., Hosseini Abhari, E., Bolok Yazdi, H. R., and Massumi, H. 2007. Curly top of cultivated plants and weeds and report of a unique Curtovirus from Iran. J. Phytopathol. 155:321-325.

Heydarnejad, J., Keyvani, N., Razavinejad, S., Massumi, H., and Varsani, A. 2013. Fulfilling Koch's postulates for beet curly top Iran virus and proposal for consideration of new genus in the family Geminiviridae. Arch. Virol. 158:435-443.

Hohn, T., and Vazquez, F. 2011. RNA silencing pathways of plants: Silencing and its suppression by plant DNA viruses. Biochim. Biophys. Acta 1809 588-600.

Hormuzdi, S., and Bisaro, D. M. 1993. Genetic analysis of beet curly top virus: Evidence for three virion sense genes involved in movement and regulation of single- and double-stranded DNA levels. Virology 193:900-909.

Horn, J., Lauster, S., Krenz, B., Kraus, J., Frischmuth, T., and Jeske, H. 2011. Ambivalent effects of defective DNA in Beet curly top virus-mediated transgenic sugarbeet plants. Virus Res. 158:169-178.

Huson, D. H., and Bryant, D. 2006. Application of phylogenetic networks in evolutionary studies. Mol. Biol. Evol. 23:254-267.

Ji, X., Zhang, H., Zhang, Y., Wang, Y., and Gao, C. 2015. Establishing a CRISPRCas immune system conferring DNA virus resistance in plants. Nat. Plants 1: Article 15144. doi:10.1038/NPLANTS.2015.144

Kaffka, S. R., Wintermantel, W. M., and Lewellen, R. T. 2002. Comparisons of soil and seed applied systemic insecticides to control Beet curly top virus in the San Joaquin Valley. J. Sugar Beet Res. 39:59-74.

Kimura, M. 1980. A simple method for estimating evolutionary rates of base substitutions through comparative studies of nucleotide sequences. J. Mol. Evol. 16:111-120.

Klute, K. A., Nadler, S. A., and Stenger, D. C. 1996. Horseradish curly top virus is a distinct subgroup II geminivirus species with rep and $\mathrm{C} 4$ genes derived from a subgroup III ancestor. J. Gen. Virol. 77:1369-1378.

Kumar, S., Stecher, G., and Tamura, K. 2016. MEGA7: Molecular evolutionary genetics analysis version 7.0 for bigger datasets. Mol. Biol. Evol. 33:1870-1874

Lam, N., Creamer, R., Rascon, J., and Belfon, R. 2009. Characterization of a new curtovirus, pepper yellow dwarf virus, from chile pepper and distribution in weed hosts in New Mexico. Arch. Virol. 154:429-436. 
Larkin, M. A., Blackshields, G., Brown, N. P., Chenna, R., McGettigan, P. A., McWilliam, H., Valentin, F., Wallace, I. M., Wilm, A., Lopez, R., Thompson, J. D., Gibson, T. J., and Higgins, D. G. 2007. Clustal W and Clustal X version 2.0. Bioinformatics 23:2947-2948.

Lee, G., Shim, H.-K., Kwon, M.-H., Son, S.-H., Kim, K.-Y., Park, E.-Y., Lee, T.-K., Lee, W.-R., Auh, C.-K., Kim, D., Kim, Y.-S., and Lee, S. 2013. A nucleic acid hydrolyzing recombinant antibody confers resistance to curtovirus infection in tobacco. Plant Cell Tissue Organ Cult. 115:179-187.

Lefeuvre, P., and Moriones, E. 2015. Recombination as a motor of host switches and virus emergence: Geminiviruses as case studies. Curr. Opin. Virol. 10: 14-19.

Martin, D. P., Murrell, B., Golden, M., Khoosal, A., and Muhire, B. 2015. RDP4: Detection and analysis of recombination patterns in virus genomes. Virus Evol. 1:1-5.

Martin, D. P., Posada, D., Crandall, K. A., and Williamson, C. 2005. A modified bootscan algorithm for automated identification of recombinant sequences and recombination breakpoints. AIDS Res. Hum. Retroviruses 21:98-102.

Montazeri, R., Shams-Bakhsh, M., Mahmoudi, S. B., and Rajabi, A. 2016. Evaluation of sugar beet lines for resistance to Beet curly top viruses. Euphytica 210:31-40.

Muhire, B. M., Varsani, A., and Martin, D. P. 2014. SDT: A virus classification tool based on pairwise sequence alignment and identity calculation. PLoS One 9:e108277.

Padidam, M., Sawyer, S., and Fauquet, C. M. 1999. Possible emergence of new geminiviruses by frequent recombination. Virology 265:218-225.

Panella, L., Kaffka, S. K., Lewellen, R. T., McGrath, J. M., Metzger, M. S., and Strausbaugh, C. A. 2014. Sugarbeet. Pages 357-396 in: Yield Gains in Major U.S. Field Crops. Crop Sci. Soc. Am. Spec. Publ. 33. S. Smith, B. Diers, J. Specht, and B. Carver, eds. Crop Science Society of America, Madison, WI.

Posada, D., and Crandall, K. A. 2001. Evaluation of methods for detecting recombination from DNA sequences: Computer simulations. Proc. Natl. Acad. Sci. USA 98:13757-13762.

Razavinejad, S., Heydarnejad, J., Kamali, M., Massumi, H., Kraberger, S., and Varsani, A. 2013. Genetic diversity and host range studies of turnip curly top virus. Virus Genes 46:345-353.

Rondon, S. I., Roster, M. S., Hamlin, L. L., Green, K. J., Karasev, A. V., and Crosslin, J. M. 2016. Characterization of Beet curly top virus strains circulating in beet leafhoppers (Hemiptera: Cicadellidae) in northeastern Oregon. Plant Dis. 100:1586-1590.

Ronquist, F., and Huelsenbeck, J. P. 2003. MrBayes 3: Bayesian phylogenetic inference under mixed models. Bioinformatics 19:1572-1574.

Sahu, P. P., and Prasad, M. 2015. Application of molecular antiviral compounds: Novel approach for durable resistance against geminiviruses. Mol. Biol. Rep. 42:1157-1162.

Sharma, N., Sahu, P. P., Puranik, S., and Prasad, M. 2012. Recent advances in plant-virus interaction with emphasis on small interfering RNAs (siRNAs). Mol. Biotechnol. 55:63-77.

Smith, J. M. 1992. Analyzing the mosaic structure of genes. J. Mol. Evol. 34: 126-129.

Soleimani, R., Matic, S., Taheri, H., Behjatnia, S. A. A., Vecchiati, M., Izadpanah, K., and Accotto, G. P. 2013. The unconventional geminivirus Beet curly top Iran virus: Satisfying Koch's postulates and determining vector and host range. Ann. Appl. Biol. 162:174-181.

Soto, M. J., Chen, L.-F., Seo, Y.-S., and Gilbertson, R. L. 2005. Identification of regions of the Beet mild curly top virus (family Geminiviridae) capsid protein involved in systemic infection, virion formation and leafhopper transmission. Virology 341:257-270

Soto, M. J., and Gilbertson, R. L. 2003. Distribution and rate of movement of the Curtovirus Beet mild curly top virus (Family Geminiviridae) in the beet leafhopper. Phytopathology 93:478-484.

Stanley, J., Markham, P. G., Callis, R. J., and Pinner, M. S. 1986. The nucleotide sequence of an infectious clone of the geminivirus beet curly top virus. EMBO J. 5:1761-1767.

Stenger, D. C. 1994. Complete nucleotide sequence of the hypervirulent CFH strain of beet curly top virus. Mol. Plant-Microbe Interact. 7:154-157.
Stenger, D. C. 1998. Replication specificity elements of the Worland strain of beet curly top virus are compatible with those of the $\mathrm{CFH}$ strain but not those of the Cal/Logan strain. Phytopathology 88:1174-1178.

Stenger, D. C., Carbonaro, D., and Duffus, J. E. 1990. Genomic characterization of phenotypic variants of beet curly top virus. J. Gen. Virol. 71:2211-2215.

Stenger, D. C., Davis, K. R., and Bisaro, D. M. 1994. Recombinant beet curly top virus genomes exhibit both parental and novel pathogenic phenotypes. Virology 200:677-685

Stenger, D. C., and McMahon, C. L. 1997. Genotypic diversity of beet curly top virus populations in the western United States. Phytopathology 87:737-744.

Stenger, D. C., and Ostrow, K. M. 1996. Genetic complexity of a beet curly top virus population used to assess sugar beet cultivar response to infection. Phytopathology 86:929-933.

Strausbaugh, C. A., Eujayl, I. A., and Foote, P. 2010. Seed treatments for the control of insects and diseases in sugarbeet. J. Sugar Beet Res. 47:105-125.

Strausbaugh, C. A., Gillen, A. M., Camp, S., Shock, C. C., Eldredge, E. P., and Gallian, J. J. 2007. Relationship of beet curly top foliar ratings to sugar beet yield. Plant Dis. 91:1459-1463.

Strausbaugh, C. A., Gillen, A. M., Gallian, J. J., Camp, S., and Stander, J. R. 2006. Influence of host resistance and insecticide seed treatments on curly top in sugar beets. Plant Dis. 90:1539-1544.

Strausbaugh, C. A., Wenninger, E. J., and Eujayl, I. A. 2012. Management of severe curly top in sugar beet with insecticides. Plant Dis. 96:1159-1164.

Strausbaugh, C. A., Wenninger, E. J., and Eujayl, I. A. 2014. Control of curly top in sugar beet with seed and foliar insecticides. Plant Dis. 98: 1075-1080.

Strausbaugh, C. A., Wenninger, E. J., and Eujayl, I. A. 2016. Length of efficacy for control of curly top in sugar beet with seed and foliar insecticides. Plant Dis. 100:1364-1370

Strausbaugh, C. A., Wintermantel, W. M., Gillen, A. M., and Eujayl, I. A. 2008. Curly top survey in the western United States. Phytopathology 98:1212-1217.

Tamura, K., and Nei, M. 1993. Estimation of the number of nucleotide substitutions in the control region of mitochondrial DNA in humans and chimpanzees. Mol. Biol. Evol. 10:512-526.

Varsani, A., Martin, D. P., Navas-Castillo, J., Moriones, E., Hernández-Zepeda, C., Idris, A., Zerbini, F. M., and Brown, J. 2014a. Revisiting the classification of curtoviruses based on genome-wide pairwise identity. Arch. Virol. 159:1873-1882.

Varsani, A., Navas-Castillo, J., Moriones, E., Hernández-Zepeda, C., Idris, A., Brown, J. K., Zerbini, F. M., and Martin, D. P. 2014b. Establishment of three new genera in the family Geminiviridae: Becurtovirus, Eragrovirus and Turncurtovirus. Arch. Virol. 159:2193-2203.

Velásquez-Valle, R., Medina-Aguilar, M. M., and Creamer, R. 2008. First report of Beet mild curly top virus infection of chile pepper in north-central Mexico. Plant Dis. 92:650.

Velasquez-Valle, R., Mena-Covarrubias, J., Reveles-Torres, L. R., Argüello-Astorga, G. R., Salas-Luevano, M. A., and Mauricio-Castillo, J. A. 2012. First report of Beet mild curly top virus in dry bean in Zacatecas, Mexico. Plant Dis. 96:771.

Wang, M.-B., Masuta, C., Smith, N. A., and Shimura, H. 2012. RNA silencing and plant viral diseases. MPMI 25:1275-1285.

Wintermantel, W. M. 2009. Curly Top. Pages 51-53 in: Compendium of Beet Diseases and Pests, 2nd ed. R. M. Harveson, L. E. Hanson, and G. L. Hein, eds. American Phytopathological Society, St. Paul, MN.

Wintermantel, W. M. 2011. Impact of curly top host plants on accumulation, competitiveness, and durability of curtovirus species. (Abstr.). J. Sugar Beet Res. 48:93.

Wintermantel, W. M., and Kaffka, S. R. 2006. Sugar beet performance with curly top is related to virus accumulation and age at infection. Plant Dis. 90:657-662.

Yazdi, H. R. B., Heydarnejad, J., and Massumi, H. 2008. Genome characterization and genetic diversity of beet curly top Iran virus: A geminivirus with a novel nonanucleotide. Virus Genes 36:539-545.

Zaidi, S. S., Mansoor, S., Ali, Z., Tashkandi, M., and Mahfouz, M. M. 2016 Engineering plants for geminivirus resistance with CRISPR/Cas9 system. Trends Plant Sci. 21:279-281. 